DOI: 10.1515/pof-2016-0019

VOLUME 8, ISSUE 3, 2016

ISSN: $2036-5438$

\title{
Austerity on the loose in Portugal: European judicial restraint in times of crisis \\ by
}

Francisco Pereira Coutinho*

Perspectives on Federalism, Vol. 8, issue 3, 2016 


\section{Abstract}

The international bailout granted to Portugal between 2011 and 2014 was conditional on the adoption by the Portuguese State of austerity measures included in a memorandum of understanding $(\mathrm{MoU})$ signed by the European Commission on behalf of the European Union (EU) and the Member States. The MoU was never published in an official journal or even translated into the Portuguese language. Its implementation caused a significant decrease in the level of protection of social rights.

The compatibility of the MoU with core principles of the rule of law and with the EU's social Constitution was never tested in court. A systemic failure in the jurisdictional system of the EU immunized the MoU to any judicial challenge. At the apex of the system, the Court of Justice of the EU declined to answer preliminary references submitted by Portuguese lower courts that questioned the compatibility with the Charter of Fundamental Rights of the EU of national budgetary measures that implemented the MoU. At the bottom, Portuguese courts either failed to properly identify the EU law acts that were the source of national austerity measures or disregarded their role as common EU law courts of ordinary jurisdiction when they bypassed the opportunity to refer a question for a preliminary ruling of the Court of Justice challenging the validity of the MoU.

\section{Key-words}

Bailouts, Charter of Fundamental Rights of the European Union, Social Constitution of the EU, Financial crisis, Portugal, Memorandum of Understanding 


\section{Introduction}

1.1.

During 2012 and 2013 Portuguese lower courts repeatedly made use of the power given by Article 267 of the Treaty on the Functioning of the European Union (TFUE) to refer questions for a preliminary ruling of the Court of Justice (of the EU) that targeted measures adopted by the Portuguese State to meet loan conditionalities stemming from a three-year $€ 78$ billion bailout program agreed with international lenders that included the EU. The program envisioned a strategy of fiscal consolidation that had the objective of reducing the deficit and public debt through the adoption of austerity measures that included tax increases and cuts in State spending coupled with the adoption of structural reforms aimed at fostering economic growth, employment and productivity.

The bailout was negotiated between April and May 2011 by the Portuguese State with a Troika composed of the International Monetary Fund (IMF), the European Central Bank (ECB) and the European Commission. Negotiation ended with the draft of three memoranda. Two of them - the Memorandum of Economic and Financial Policies (MEFP) and the Technical Memorandum of Understanding (TMU) - were sent as an attachment to a letter of intent addressed by the Portuguese State to the IMF`s Executive Board that asked for access to the fund's resources. The other - the Memorandum of Understanding on Specific Economic Policy Conditionality (MoU) between the Portuguese State and the European Commission- was signed in Lisbon on 17 May 2011. The first disbursement of financial assistance loaned by the EU and by Member States followed the entry into force of the MoU. Further instalments were conditional on a Commission's positive review - enacted in liaison with the ECB - that took place on a trimestral basis during the duration of the programme. The second updated version of the MoU, dated 9 December 2011, made a loan disbursement conditional on the adoption in 2012 of a budgetary law that:

'reduce(d) wages for all general government sector employees in 2012 by (i) suspending the $13^{\text {th }}$ and $14^{\text {th }}$ monthly salary payments for those workers with monthly salaries of EUR 1,000 or more, ii) suspending on average and in a progressive way the equivalent of one of those two salaries for those workers with 
monthly salaries between wage of EUR 485 and EUR 1,000. Similar measures will apply to all State Owned Enterprises classified inside or outside the perimeter of the government sector, and in any other public entity even if falling outside the perimeter of the government sector.'I

The Portuguese Budget Act for 2012 raised the public wages cut threshold to EUR 1,100 for suspending both the 13th and 14th monthly salaries, and to between EUR 600 and EUR 1,100 for implementing the progressive suspension [Article 21 of Law 64B/2011, of 30 December 2011 (State Budget Act for 2012)]. The amendment was accepted by the Commission and the ECB because the rise in State expenditures was compensated by revenue obtained through an increase in the tax rate applicable to capital gains and investment income (e. g. dividends and interest payments). ${ }^{\text {II }}$

In Fidelidade Mundial and Via Directa, a Portuguese union - the Sindicato Nacional dos Profissionais de Seguros e Afins (National Union of Insurance Professionals) - sought the restitution of the collectively agreed holiday and Christmas allowances that were suspended by the State Budget Act for 2012 in State owned insurance enterprises. The referring courts - the Tribunal do Trabalho de Lisboa and the Tribunal do Trabalho do Porto (Lisbon and Oporto Labour Courts) - questioned the Court of Justice as to whether these measures breached fundamental rights protected by the Charter of Fundamental Rights of the EU (Charter), namely the rights to equality and non-discrimination [Articles 20 and 21 (1)] and to fair and just working conditions [Article 31 (1)]. ${ }^{\mathrm{III}}$

On 26 June and 21 October 2014, the Court of Justice declared the references inadmissible based on its lack of jurisdiction for reviewing national law vis-à-vis the Charter. ${ }^{\text {IV }}$ The Luxembourg court claimed that the austerity measures included in the State Budget for 2012 were outside its jurisdiction, which solely relates to matters falling within EU competence. The Court recalled an earlier decision from 7 March 2013 in which it had already rejected on the same grounds of inadmissibility a Portuguese preliminary reference that challenged a similar austerity measure included in the State Budget Act for 2011. ${ }^{\mathrm{V}}$

In Sindicato dos Bancários do Norte, the Court declared that in accordance with its settled case-law, the requirements flowing from the protection of fundamental rights within the EU legal order are only binding on Member States when they are implementing EU law [Article 51 (1) of the Charter]. Moreover, Article 6 (1) of the Treaty of the European Union (TEU) that provides that while the Charter is binding it neither creates new EU 
competences nor modifies existing ones. Since the referring Portuguese court (Tribunal do Trabalho do Porto) had provided no elements from which it could be considered that the contested national provision was implementing EU law, the Court of Justice found itself without competence to decide on the preliminary reference. ${ }^{\mathrm{VI}}$

Notwithstanding the fact that the austerity measures included in the State Budget Act for 2012 were adopted after the bailout and in accordance with the MoU - a fact also neglected in the references submitted by the Portuguese courts in Fidelidade Mundial and Via Directa -, the Court of Justice declared that the doubts 'share(d) the same nature, ${ }^{\text {,VII }}$ and the questions submitted were 'analogous' Bancários do Norte. In both cases the questions submitted did not contained any concrete element enabling the view to be taken that the 2011 or the 2012 Budget Law sought to implement EU law. ${ }^{\mathrm{IX}}$

\section{2 .}

Bailout instruments such as the MoU have been considered the most important social source in the history of the EU (Kilpatrick 2014: 393). Their implementation in Portugal heralded a dramatic erosion of social rights through the adoption of drastic cuts in a wide range of welfare allowances and in public investment in housing, education and health (Nogueira de Brito 2014: 68-73). How is it then possible that the compatibility of the MoU with the EU's social Constitution was never tested in court? In this article I argue that a systemic failure in the jurisdictional system of the EU immunized the MoU to any kind of judicial review. At the apex of the system, the Luxembourg court failed when it refused to answer the preliminary references submitted by Portuguese lower courts. The MoU was signed by an EU institution within the framework of EU legislation (section one). That means that it was a binding EU legal act that could be challenged on multiple EU law grounds (section two). By not tracing the genealogy of the austerity measures adopted by the Portuguese government to the $\mathrm{MoU}$, the Court of Justice was simply nowhere to be seen during the bailout (section three). At the bottom of the jurisdictional system of the EU, Portuguese courts failed to properly identify EU legal acts that were the source of national budgetary provisions that foresaw austerity measures; moreover, they disregarded their role as common EU law courts of ordinary jurisdiction when they did not refer 
questions for a preliminary ruling of the Court of Justice challenging the validity of the MoU (section four). ${ }^{\mathrm{x}}$

\section{The EU genealogy of the Portuguese bailout legal instruments}

2.1.

On 7 May 2010, on the eve of what was named - in retrospective quite hyperbolically 'the most dramatic weekend in EU bistory' (Ruffert 2011: 1779), the Heads of State or Government of the Eurozone reaffirmed their commitment to explore 'the full range of means available to ensure the stability of the euro area'. Something had to be done to dam the systemic risk of a domino effect on the solvency of Eurozone Member States following the bailout of Greece agreed just days before the summit (on 2 May 2010). If countries such as Portugal, Italy, Ireland or Spain were to lose access to international debt markets the survival of the Euro could be at peril. The Commission was thus mandated to draft a European stabilization mechanism to preserve financial stability in Europe. ${ }^{\mathrm{XI}}$

On 10 May 2010, Ecofin approved the establishment of a European stabilization mechanism based on an EU regulation and a Special Purpose Vehicle adopted by Eurozone Member States pursuant to their national constitutional requirements. Regulation (EU) 407/2010 adopted the next day created the European Financial Stabilisation Mechanism (EFSM). On 7 June 2010, the European Financial Stability Mechanism (EFSF) was incorporated in Luxembourg as a private company. The activation of both bailout mechanisms was limited by the adoption of 'strong conditionality, in the context of a joint EU/IMF support', and based 'on terms and conditions similar to the IMF'. ${ }^{\mathrm{XII}}$

Conditionality in this context was necessary to comply with the no-bailout clause of Article 125 TFEU. ${ }^{\mathrm{XII}}$ The latter only permits the granting of financial assistance by the EU and between Eurozone Member States provided that the conditions attached to such assistance are such as to prompt the beneficiary Member State to implement sound budgetary policies. ${ }^{\mathrm{XIV}}$

\section{2.}

Regulation (EU) 407/2010 is based on Article 122 (2) TFEU that allows financial assistance to be granted, under certain conditions, to a Member State facing difficulties or 
seriously threatened by exceptional occurrences beyond its control. Surprisingly, in 2010 the 'exceptional occurrences' were not identified with systemic problems in the Economic and Monetary Union, but with the 'unprecedented global financial crisis and economic downturn', which was responsible for a recession that could not be explained as a negative peak of an economic cycle [Recital 3 of Regulation (EU) 407/2010].

The EFSM was deemed transitory and merely instrumental for the stabilization of financial markets in the context of the global banking crises that started with the Lehman Brothers bankruptcy of September 2008. The mechanism allowed an EU bailout of Eurozone Member States for only up to $€ 60$ billion through loans and lines of credit in the international capital markets. Member States did not directly undertake any liability, as the EFSM funded itself through loans secured by the EU budget [Articles 2 (1) and 5 of Regulation (EU) 407/2010].

\section{3 .}

Access to the EFSM mimics IMF's bailouts. ${ }^{\mathrm{XV}}$ A Eurozone Member State facing 'exceptional financial occurrences beyond its control presents a draft economic and financial adjustment programme to the Commission and to the Economic and Financial Committee of the Council. The draft is based on an assessment of the financial needs of the Member State previously discussed with the Commission and the ECB [Article 3 (1) Regulation (EU) 407/2010]. The draft is afterwards presented to the Council that, acting by a qualified majority on a loan proposal of the Commission, adopts a decision that includes: i) the amount, the average maturity, the pricing formula, the maximum number of instalments, the availability period of the Union financial assistance and other rules; ii) the adjustment programme prepared by the beneficiary Member State; and iii) the general economic policy conditions attached to the Union's financial assistance. The general economic policy conditions are established by the Commission in liaison with the ECB with a view to reestablishing a sound economic or financial situation in the beneficiary Member State and to restoring its capacity to finance itself on the financial markets [Articles 3 (3) and (4) of Regulation (EU) 407/2010]. The beneficiary Member State and the Commission then enter into negotiation on the financial conditions of the specific economic policy conditions attached to the financial assistance. The negotiation ends with the signature of the MoU [Articles 3 (5) of Regulation (EU) 407/2010]. 
The first disbursement of financial assistance is released after the signature of the MoU. Further instalments are conditional on a regular review made by the Commission of the economic policies of the Member State and, particularly, the fulfilment of the conditionality included in the MoU (Article 4 of Regulation (EU) 407/2010). Changes in the general economic policy conditionality are negotiated between the Commission and the beneficiary Member State and afterwards included in a revised draft economic and financial adjustment programme prepared by the Member State. The Council, acting by a qualified majority, approves the adjustments to the programme and revises the decision that granted financial support to the Member State in order to incorporate the amendments to the general economic conditions proposed by the Commission. The disbursement of the next instalment of the loan follows the signature by the Commission and the Member State of an updated version of $\mathrm{MoU}$ revised in accordance with the amendments introduced in the Council's decision [Article 3 (6) and (7) of Regulation 407/201].

\section{4 .}

The EFSF was founded through a public deed made in Luxembourg on 7 June 2010 that incorporated a public limited liability company under Luxembourg law (Société Anonyme) that had the State of Luxembourg as its sole shareholder. ${ }^{\mathrm{XVI}}$ Immediately afterwards, the EFSF signed with the Ministers for Finance of the Eurogroup a framework-agreement which is subject to English law. The framework-agreement establishes the institutional framework of the EFSF, the terms and conditions upon which the EFSF may grant financial assistance, issue debt and provide guarantees, as well as the proceedings of access and the conditionality of financial assistance. ${ }^{\mathrm{XVII}}$

The option for private law instruments for the creation of the EFSF can be explained with political reasons related to the fear that the internal procedure of approval of an international treaty could be blocked by parliaments or directly rejected by the people in referenda. ${ }^{\text {XVII }}$ This foundational path raises, however, legal problems as many of the matters included in the by-laws and in the framework agreement of the EFSF clearly transcend the boundaries of private law (Tuori 2012: 30).

This transcendence seems to the case in the tasks given to the Commission and the ECB to negotiate and monitor the fulfillment of the measures foreseen in the MoU, a necessary condition to the disbursement of financial assistance under the loan agreement 
adopted between the EFSM and the Member States seeking assistance. ${ }^{\text {XIX }}$ Although Article 13 (2) TUE states that EU institutions 'shall act within the limits of the powers conferred on it in the Treaties, and in conformity with the procedures, conditions and objectives set out in them', in Pringle the Court of Justice clarified that Member States are 'entitled, in areas which do not fall under the exclusive competence of the Union, to entrust tasks to the institutions, outside the framework of the Union'; these are similar to those given to the Commission and the ECB in the EFSF. ${ }^{\mathrm{Xx}}$ However, as the Luxembourg court declared in Pringle and restated in Ledra, the tasks conferred on the Commission and the ECB by international treaties that solely bind the Member States 'do not alter the essential character of the powers conferred on those institutions by the EU and FEU Treaties. $\mathrm{XXI}$

Another example of the public law nature of the framework-agreement is the submission to the jurisdiction of the Court of Justice of disputes between the Member States and to the jurisdiction of Luxembourg common courts of disputes between the EFSF and Member States [Article 16 (2)]. ${ }^{\text {XXI }}$ The adoption of a dual system implies that the legal relationships established between Member States are inherently different (and have a public legal nature) from the ones that involve the Member States and the EFSF (which have a private legal nature). In this regard, it is also not clear whether the Treaties authorize the transformation of the Court of Justice into an arbitration forum for the resolution of disputes emerging from a contract subjected to English law. Article 273 TFEU states that 'the Court of Justice shall have jurisdiction in any dispute between Member States which relates to the subject matter of the Treaties if the dispute is submitted to it under a special agreement between the parties'. This provision aims at protecting the uniformity of EU law, which could be at risk by decisions of judicial bodies in matters connected with the Treaties. Article 273 TFUE was introduced in the Rome Treaty to solve disputes emerging from international treaties adopted between Member States using their ius tractuum (Piçarra 2013: 51). Its wording does not exclude the argument that the 'special agreement' (Article 273 TFEU) between Member States could be a provision included in a contract established between Member States and a private company, particularly in a case were the jurisdiction of the Court of Justice concerns disputes that only involve Member States in matters that are clearly related to the subject-matter of the Treaties. ${ }^{\text {xxIII }}$

The EFSF was established by sovereign States to rescue other sovereign States with the assistance of EU institutions. It is inherently a public international law legal instrument that 
does not lose that ethos by the magical will of States. Any other opinion would reduce to a mere formality the distinction between public and private law and, in the case of the Portuguese constitutional legal order, opens the path to a "Constitutional fraud" through the governmental circumvention of the procedure applicable to the approval of international treaties. With the EFSF, the Portuguese State undertook obligations that potentially have an impact in the financial and economic sovereignty of the State that had to be authorized by the Portuguese Parliament. In fact, it is hard to include these in the general policy competence of the Government to 'adopt acts and take steps necessary to the promotion of social and economic development and to the satisfaction of collective needs. ${ }^{\mathrm{XXIV}}$ The use of public international law legal instruments would also require the authorization of the Portuguese President. ${ }^{\mathrm{XxV}}$ Only the intervention of both the Parliament and the President could have granted the EFSF the democratic legitimacy required by the Constitution to internationally bind the Portuguese State. The EFSF was thus created in violation of the commitment made on 9 May 2010 by the Governments of the Eurozone Member States to provide financial assistance to Eurozone Member States through a Special Purpose Vehicle established 'pursuant to their national constitutional requirements.' $\mathrm{xxvI}$

\section{5 .}

Financial assistance under the EFSF is triggered by a request of a Eurozone Member State. A negotiation follows, in which the Commission, in liaison with the ECB, negotiates a MoU that includes financial and economic measures based on a Council decision adopted in accordance with Article 136 TFEU. ${ }^{\mathrm{XXVII}}$ The Commission signs the MoU after the approval of the latter by the Eurogroup Working Group. If an EFSM MoU has already been adopted, a separate EFSF MoU is not needed, provided that the former also covers EFSF stability support. Following the approval of the relevant MoU, the Commission, again in liaison with the ECB, proposes to the Eurogroup Working Group the main terms of the loan agreement. The technical details of the loan agreement are afterwards negotiated between the beneficiary Member State and the EFSF [Article 2 (1) of the EFSF Framework-Agreement].

The initial disbursement of financial assistance is released after the signature of the MoU. Further instalments are conditional on a unanimous decision of the Eurozone Member States based on a report presented by the Commission, in liaison with the ECB, in 
which it analyses the compliance by the beneficiary Member State with the terms and the conditions set out in the MoU and in the Council Decision relating to it [Article 3 (1) of the EFSF Framework-Agreement].

\section{6 .}

On 6 April 2011 the Portuguese Government requested the Commission for financial assistance. The answer arrived two days later in a joint declaration of the Eurogroup and Ecofin that made EFSM and EFSF support conditional on the adoption of a 'financial and economic adjustment programme' supported by strict conditionality. ${ }^{\mathrm{XXVIII}}$ The negotiation that followed ended on 13 May 2011 when the Portuguese Government and Portuguese Central Bank sent to the European Commission, the Eurogroup and the ECB a letter of intent, with a MoU as an attachment, that included the project of an adjustment program.

On 17 May 2011, the Council granted EU/EFSM financial assistance to Portugal through the Implementing Decision 344/2011/EU. ${ }^{x x x}$ On the same day, ${ }^{x x}$ the Portuguese Government and the Commission signed a MoU that foresaw the adjustment program and specified the conditions of the financial support foreseen in the Council Implementing Decision. ${ }^{x x I}$

The request for EFSF financial assistance was sent on 13 May 2011 by the Portuguese Government to the President of the Eurogroup in an attachment to a letter of intent. The answer arrived four days later (17 May 2011), when the Ministers for Finance of the Eurogroup decided to loan Portugal $€ 26$ billion (a third of the bailout) through the EFSF. ${ }^{\text {XXXII }}$ As a condition for the bailout it was established that the EFSF loan agreement with Portugal had to specify that the disbursements there under had to be subject to compliance with the conditions set forth in the memorandum signed on that same day between the Commission, the Portuguese Government and the Bank of Portugal. ${ }^{\text {XxXIII }}$ This was the memorandum (the $\mathrm{MoU}$ ) that detailed the general economic policy conditions as embedded in Council Implementing Decision 2011/344/EU on granting Union financial assistance to Portugal, whose signature conditioned access to the EFSM. Thus, no independent EFSF memorandum was signed in the Portuguese bailout. ${ }^{\text {XxIv }}$

The implementation of the adjustment programme created an economic recessive spiral that inevitably led to the impossibility of accomplishing the budgetary targets included in the MoU. For that reason, after trimestral evaluations of the programme by the 
Commission and the ECB, the Council reviewed the general economic policy conditions attached to the financial assistance. The amendments included new measures for the adjustment programme that were afterwards included in nine (!) updated versions of the MoU. Each new update had to be signed by the Commission and the Portuguese authorities to allow further disbursements of loan instalments granted under the EFSM and the EFSF. ${ }^{x x x v}$

\section{The legal nature of the MoU}

In the first opportunity it had to review the constitutionality of financial austerity measures adopted after the bailout, the Portuguese Constitutional Court had no doubts about the binding legal nature of the memoranda:

'The (adjustment) programme determines the adoption of some previous actions by the Portuguese authorities including several legal instruments that were approved, on the one side, by the Portuguese Government and, on the other, by the Executive Council of the IMF, as well as by the Portuguese Government and the European Commission (for the EU) and by the ECB. Thus, the Portuguese Government and the IMF approved the (TMU) and the (MEFP) that establish the conditions of the IMF financial assistance to Portugal. Furthermore, between the Portuguese government and the EU (the MoU) was signed. (The MoU) was adopted according to Council Regulation (UE) 407/2011, of 11 May 2010, that establishes the EFSM, and in particular its article 3 (5) that establishes the general conditions of economic policy included in the Council Implementing Decision 2011/344/UE, on granting Union financial assistance to Portugal.

These memoranda are binding to the Portuguese State because they are based in legal instruments (...) of international law and EU law that are incorporated through Article 8 (2) of the (Portuguese) Constitution. The (MEFP) and the (TMU) are based in Article V, Section 3, of the Agreement of the IMF , and the (MoU) is ultimately based in article 122 (2) TFEU. Such documents impose the adoption by the Portuguese State of the measures contained therein as a condition of the phased fulfilment of the loan agreements (...).

From the wording of the memoranda, as well as from the Council of Ministers Resolution 8/2011, of 5 May 2011 [published in the Diário da República (Official Journal), II Série, from 17 May 2011], is clear that as a consequence of the (bailout program), Portugal must adopt during a three year period several measures and legal acts, some having a structural nature, connected with public finances, financial stability and competitiveness. ${ }^{\text {XxxvI }}$ 
The MoU was an atypical EU law act (Pereira Coutinho 2013: 116; Kilpatrick 2014: 411): its entry into force and execution conditioned the application of the Council decision that implemented a Regulation based on article 122 (2) TFEU that created the financial mechanism (EFSM) that allowed the EU to bail-out Eurozone Member States. ${ }^{\text {XxxVII }}$ As it was signed by the Commission on behalf of the EU [article 2 (2) of Decision 2011/344/EU], it could be qualified as 'an act of an institution' (Article 267 (1) of the TFEU) and submitted to a validity review by the Court of Justice under the preliminary reference procedure.

The MoU created binding legal effects on both of its signatories. For the EU, the fulfilment of the MoU's conditionality obliged the Council to authorize the payment of the scheduled loan instalments to the Portuguese State. A Council decision that denied such a disbursement could be appealed through the annulment procedure (Article 263 TFUE). For the Portuguese State, Council Recommendations taken in the framework of the excessive deficit procedure refer to the obligation to implement the measures as laid down in the Council Implementing Decision 2011/344/EU and further specified in the MoU and its subsequent supplements. ${ }^{\text {xxxiII }}$ The failure to comply with the MoU could ultimately determine the adoption by the Council of sanctions foreseen in article 126 (11) TFEU.

The eventual qualification of the MoU as soft law would not exclude the admissibility of a preliminary reference on its validity. In Grimaldi the Luxembourg court declared that non-binding EU law acts, such as recommendations, may be submitted to a reference for a preliminary ruling when such acts intend to produce legal effects vis-à-vis third parties, namely when they 'they are designated to supplement binding EU law provisions, ${ }^{\text {,xxix }}$ which in this case were the Council Regulation (UE) 407/2011 and the Council Implementing Decision 2011/344/EU.

\section{The MoU, the Charter and the rule of Law}

\section{1.}

If the MoU were an atypical EU law, the national budgetary provisions under review in the preliminary references submitted by Portuguese courts in Fidelidade Mundial and Via Directa would be 'implementing Union law' [Article 51 (1) of the Charter]. Those provisions 
transposed almost ipsis verbis into national law the bailout conditionality foreseen in the Council Implementing Decision 2011/344/EU and in the MoU.

In Fransson, the Court clarified that fundamental rights guaranteed by the Charter must be complied with where national legislation 'falls within the scope of European Union' rather than only when they are 'implementing EU law'. The application of the Charter is not limited to cases where national law formally transposes EU law. According to the Court of Justice, 'situations cannot exist which are covered (...) by EU law without (...) fundamental rights (protected by the Charter) being applicable. The applicability of EU law entails applicability of the fundamental rights guaranteed by the Charter. ${ }^{\mathrm{XL}}$

\section{2 .}

The Commission and the ECB were key institutions in the bailout. When negotiating, signing and assessing the conditionality imposed on Portugal, the former had to assure that the Charter and the social acquis of the EU was respected. In the role of guardian of the Treaties as resulting from Article 17(1) TEU, the Commission should have refrained from signing and implementing a MoU whose consistency with EU law it had every reason to doubt. ${ }^{\mathrm{XLI}}$

The MoU foresaw cuts to health and education, pensions and other social benefits, as well as reductions in the size and pay of the public sector. ${ }^{\text {XII II }}$ In Fidelidade Mundial and Via Directa, Portuguese courts questioned the compatibility of pay cuts in the public sector with the workers 'right to working conditions which respect his or her health, safety and dignity' [Article 31 (1) of the Charter]. But many other legislative acts enacted to comply with the MoU could have also been challenged on their compatibility with the EU social constitution, such as those related to changes introduced in the dismissal law and in the collective bargaining system (Koukiadaki 2014: 28-30). The lack of EU competence to impose social austerity could also be a ground for challenging the $\mathrm{MoU}$ and the Council decisions that support it (Costamagna 2012: 15-16; Barnard 2013: 267-268). XLIII

When reviewing the validity of the MoU, the Court of Justice would also have been given the opportunity to address breaches of core principles of the rule of law (Kilpatrick 2015: 349), and in particular the breach of the principle of legal certainty and legitimate expectations (Martín Rodríguez 2016: 266-268; 277-278). The latter forms part of the EU legal order and must respected by EU institutions and Member States when implementing 
EU law. ${ }^{\text {XLIV }}$

In order to meet the requirements of legal certainty, individuals must have the possibility of determining the source of the national measures imposing obligations upon them and, therefore, "not only must the national legislation be published but also the measure of EU law which obliges the Member States to take measures imposing obligations on individuals. ${ }^{\mathrm{XLV}}$

The MoU was not published in the Official Journal of the EU and had a single official version in English. Portuguese laypeople affected by unprecedented austerity were unable to access through an official source and read in their mother tongue the legal document that most seriously affected their daily life during the three (very long) years. ${ }^{\text {XLVI }}$

The MoU and its updates were not considered sufficiently important to be published in the L (Legislation) Series of the Official Journal of the European Union. The document was eventually published as an annex to an edition of the Directorate-General for Economic and Financial Affairs of the European Commission named European Economy Occasional Papers. Since it was not published in the Official Journal of the European Union, the MoU was unable to produce legal effects. ${ }^{\text {XVIII }}$

Publication in the Official Journal would also have avoided the problem caused by the decision to adopt the English language as 'the original and official version' of the MoU. ${ }^{\mathrm{XLVIII}}$ This was a clear violation of the principle of linguistic diversity of the EU protected by Article 3 (3) TUE that states that the Union 'shall respect its rich cultural and linguistic diversity, and shall ensure that Europe's cultural heritage is safeguarded and enhanced and by Article 4 (1) according to which the Union 'respects the equality of Member States before the Treaties as well as their national identities. Given that article 4 of the EEC Council Regulation 1/1958 establishes the Portuguese language as one of the twenty-four official languages used by EU institutions, and since the MoU specifies a Council decision addressed to the Portuguese Republic (Article 5 of Council Implementing Decision 2011/344/EU), the Commission was obliged to sign the official version of the $\mathrm{MoU}$ in the Portuguese language. ${ }^{\mathrm{XLIX}}$

4.3.

The Fidelidade Mundial and Via Directa decisions of inadmissibility displayed a surprising and unwelcome restraint by the Court the Justice. 'Wherever EU goes, fundamental rights must go too' could be the motto for the Court's recent case law (Kilpatrick 2015: 352). In the Kadi 
cases the Court did not refrain from making a fundamental rights review of anti-terrorist decisions of the Council. ${ }^{\mathrm{L}}$ Kadi was tantamount to the idea that the EU is a union based on the rule of law in which all acts of its institutions are submitted to review of their compatibility with, in particular, the Treaties, general principles of law and fundamental rights. ${ }^{\mathrm{LI}}$ When asked to rule on measures adopted in a situation of financial and economic emergency, the Court could not have stayed dormant when questioned with possible breaches of fundamental rights based on legislation clearly stemming from EU law sources. It had also the constitutional obligation to check the respect by EU institutions of core values of the rule of law during their involvement in the bailout of Member States.

The Court of Justice intervention was all the more necessary because national courts were prohibited from reviewing the validity of MoUs. Assuming the role of a constitutional court within a concentrated system of constitutional judicial review, the Court of Justice pre-empted all competence to declare that an EU act is invalid; the exclusivity of that jurisdiction having the purpose of guaranteeing legal certainty by ensuring that EU law is applied uniformly. ${ }_{\text {LII }}$ National courts may consider the validity of an EU law act, but they are not endowed with the power to declare such an act invalid themselves. ${ }^{\text {LIII }}$ This judicial stance is a paragon of judicial activism (Vilhena de Freitas 2015: 176), as the wording of article 267 (3) TFUE seems to allow national lower courts themselves to trump the application of invalid EU law.

\section{Portuguese courts and the MoU}

5.1.

One of the essential features of the jurisdictional system of $\mathrm{EU}$ is that it is organized according to the principle of subsidiarity (Piçarra and Pereira Coutinho 2012: 74). The Treaty of Rome rejected the creation of a federal system of courts and instead gave the responsibility to apply EU law in the Member States to national courts, which thereby became 'ordinary courts of EU law.', LIV

The inertia of the Court of Justice during the bailout may be partially linked to the behaviour of Portuguese courts. The latter either failed to properly identify the EU legal instruments that were responsible for the national austerity measures, or simply disregarded their role as common EU law courts of ordinary jurisdiction when they did not refer a 
question for a preliminary ruling of the Court of Justice regarding the validity of the MoU.

\section{2 .}

In Fidelidade Mundial and Via Directa, Portuguese lower courts (Tribunal do Trabalho do Porto e Lisboa) failed to properly identify the EU law act (the $\mathrm{MoU}$ ) that was being implemented by the Portuguese Parliament in the State Budget Act for 2012. The questions submitted were declared inadmissible because they referred to the compatibility of national law with the Charter. Article 267 TFEU is based in a clear separation of functions with national courts, according to which the Court of Justice solely has the power to rule on the interpretation or validity of EU law provisions on the basis of the facts which the national court puts before it, ${ }^{\mathrm{LV}}$ and has no jurisdiction either to apply EU law to a specific case or to decide upon the validity of a provision of domestic law in relation to EU law. ${ }^{\text {LVI }}$

The poor drafting of the preliminary references submitted in Fidelidade Mundial and Via Directa may be explained by the incapacity of Portuguese lower courts to decipher the soft and hard forms of law used by the Troika institutions during the bailout. ${ }^{\text {LVII }}$

In the blueprint used for the Portuguese bailout - the IMF's programs - memoranda are documents prepared by States seeking financial support. They essentially show the political commitment that the States seeking financial assistance are willing to repay the loans granted by the Fund [Article 5 (3) of the Articles of Agreement of the IMF]. Contrary to the statement of the Portuguese Constitutional Court quoted above in section two, IMF memoranda are not binding legal documents. The breach of these memoranda by the State seeking assistance does not entail any international State responsibility.

IMF financing is based on a unilateral decision from the Executive Board of the IMF that specifies the terms and conditions of the loan:

'A Fund arrangement is a decision of the Executive Board by which a member is assured that it will be able to make purchases or receive disbursements from the Fund in accordance with the terms of the decision during a specified period and up to a specified amount. Fund arrangements are not international agreements and therefore language having a contractual connotation will be avoided in arrangements and in program documents.'LVIII 
The Fund arrangement is not an approval of the memoranda submitted by the State seeking assistance. The memoranda are substantially broader that the Fund's arrangement, and include measures that are not conditions of the loan. The distinction between the Fund arrangement and State memoranda creates a great deal of opacity because the IMF does not publically distinguish the measures that are suggested to the States to be included in the memoranda (fund-supported programs) from measures that are a condition for the financial assistance and are mentioned in the Fund's arrangement (program-related conditions) (Siegel 2002: 581). This legal and political conundrum is frequently used by governments to approve unpopular measures with the argument that they are a condition imposed by the IMF. LIX

EU institutions involved in the bailouts followed the IMF modus operandi and identified the $\mathrm{MoU}$ as national law. ${ }^{\mathrm{LX}}$ This may explain why the MoU was not published either in Portuguese or in the EU's official journal.

Tracing the EU origin of the austerity measures included in the State budget Act for 2012 was not a simple task for Portuguese lower courts. However, this statement does not hold true for an institution with the resources of the Court of Justice:

'Whilst the Court has consistently held that, in the context of the application of Article (267 TFEU), it has no jurisdiction to decide whether a national provision is compatible with $(\mathrm{EU})$ law, it may, none the less, extract from the wording of the questions formulated by the national court, and having regard to the facts stated by the latter, those elements which concern the interpretation of (EU) law, for the purpose of enabling that court to resolve the legal problems before it.'LXI

It was a notorious fact that the Fidelidade Mundial and the Via Directa preliminary references were made after the bailout. This should have been enough for the Court of Justice to factually distinguish those cases from the preliminary reference submitted in Sindicato dos Bancários do Norte. Moreover, the national provision that was mentioned in the preliminary reference submitted by Portuguese courts (Article 21 of the State Budget for 2012) stated that the suspensions of the holiday and Christmas monthly pay were to be implemented 'during the period of application of the Economic and Financial Assistance Programme (PAEF). 'LXII Thus, it was simply not accurate to declare that 'the order for reference did not contain(ed) any specific evidence to support the view that (the national provision) was intended to implement 
EU law. ${ }^{\mathrm{LXXII}}$

Advocate General Whal opinion that the Court of Justice's rulings on its lack of jurisdiction to review bailout instruments were prompt by a failure of individuals and national courts to explain the applicability of the Charter to national austerity measures, is much too deferential to the Court of Justice. ${ }^{\text {LXIV }}$ The latter should have ex officio redrafted the questions submitted by Portuguese courts in Fidelidade Mundial and in Via Directa. Given the importance of these preliminary references - they addressed measures that seriously affected the lives of millions -, the restrictive approach to admissibility adopted in these cases conflicts with the role of the Luxembourg court as the constitutional guardian of the rule of law and fundamental rights in the EU.

\section{3 .}

The Portuguese Constitutional Court emerged during the financial crisis as a key player in the domestic political system when it had to address the compatibility with the Constitution of legislative acts that established all sorts of austerity measures. After the decision on the State Budget for 2012 (Case 353/2012), the Court was even identified as a sort of "Don Quixote fighting the windmills of austerity" when it rejected the suspension of two months of salary allowances for public servants and pensioners based on the violation of the principle of equality (Article 13 of the Constitution). ${ }^{\mathrm{LXV}}$

Such an image is completely at odds with the fact that from the outset of the crisis, the Portuguese Constitutional Court made every effort to internalise the European and international obligations of the Portuguese State. In case 396/2011 (21 September 2011) (State Budget 2011) it declared that the austerity measures were important to enforce the Growth and Stability Pact obligations. In case 353/2012 (5 July 2012) (State Budget

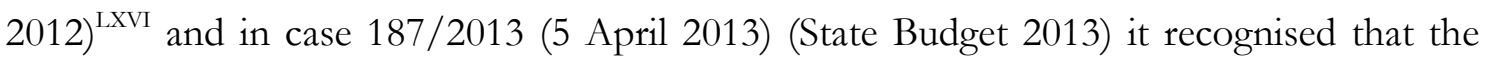
memoranda signed by the Portuguese Government with international and European institutions were legally binding to the extent that they were based on international law and EU law instruments. In case 602/2013 (20 September 2013) (Labour Code) and in case 794/2013 (40-Hour work week) it went through a detailed examination on how the provisions under review were a result of a direct transposition of the MoU into national law. In case 862/2013 (19 December 2013) (Pensions convergence) it declared that the permanent cuts in pensions proposed by the government were broader than those inserted 
in the original version of the MoU. Finally, in case 575/2014 (14 September 2014) (Special Sustainability Contribution) the Court considered that the objective set forth in recommendations adopted in the context of the excessive deficit procedure was binding and declared that, although Article 4 (2) TUE obliges the EU to respect the supremacy of Member States constitutions, the constitutional principles of equality, proportionality and the protection of legitimate expectations stemmed from the rule of law and 'belonged to an European common legal heritage' that also binds the EU, thereby ignoring possible conflicts that could emerge from different balancing of those principles by national and European courts. ${ }^{\text {LXVII }}$ In the decisions that trumped austerity measures there is always an implicit caveat that the national provisions that breached the Constitution were not included in the MoU. In other words, they were a direct result of a political option of the Portuguese State and, therefore, had to be reviewed according to the usual constitutional standards of adjudication. ${ }^{\text {LXVIII }}$

In the decision on the State Budget for 2012 (5 July 2012) (Case 353/2012), the Portuguese Constitutional Court was able to avoid addressing the constitutionality of austerity measures that stemmed directly from bailout conditionality by declaring - against all evidence - that the MoU, although binding, 'did not foresee any suspension of the holiday and Christmas monthly salary payments or of any other similar measure. ${ }^{\text {LXIX }}$

A more coherent, though to a large extent still quixotic, approach would have been to question the validity of the MoU by sending a preliminary reference to the Court of Justice - it would have been the first in the history of the Portuguese Constitutional Court. ${ }^{\text {Lxx }}$ Such a reference would immediately acquire enormous resonance and thus be politically much harder to ignore.

\section{Conclusion}

The MoU specified bailout conditionality included in the Council implementing decision that authorized EU financial assistance to Portugal. It also contained obligations of the Portuguese State that stemmed from the excessive deficit procedure. Being EU law, the MoU was not exempt from judicial review by the Court of Justice. The EU is a union based on the rule of law in which all acts of its institutions are subject to review of their compatibility with, in particular, the Treaties, general principles of law and fundamental 
rights. ${ }^{\text {LXXI }}$

The intervention of the Court of Justice during the bailout was also crucial to preserve some degree of intergovernmentalism in the EU. The economic and financial policies of a debtor Member State were dictated during three years by EU institutions (the ECB and the Commission) that essentially deferred to the interests of creditor Member States expressed in the decisions of an informal institution created at the margin of the EU political system (the Eurogroup). These EU institutions were also used in international financial mechanisms (first the EFSF and afterwards the ESM) that are not sufficiently accountable to the European Parliament or to national parliaments (Fischer-Lescano 2014: 39-40; López Escudero 2015: 425-428). A judicial counterweight was thus crucial to mitigate this increasing legitimacy (and democratic) deficit in European integration.

By signalling in Ledra that it will review the compatibility of ESM memoranda with the Charter in order to assess the fulfilment of the obligations of the Commission as the guardian of the Treaties, ${ }^{\text {LXXII }}$ the Court of Justice took a stance that could had anticipated years before in Fidelidade Mundial and Via Directa. ${ }_{\text {LXxII }}$

\footnotetext{
* Professor at Faculdade de Direito da Universidade Nova de Lisboa (Lisbon Nova Law School). Member of CEDIS - I \& D Research Center for Law and Society. Email: fpereiracoutinho@,fd.unl.pt.

I Portugal. Memorandum of Understanding on Specific Economic Policy Conditionality. Second Update - 9 December 2011, para. 1.8., i) (European Commission, 2011: 86-87).

II Portugal. Memorandum of Understanding on Specific Economic Policy Conditionality. Second Update -9 December 2011, para. 1.8., i), footnote 15 (European Commission, 2011: 86-87).

III ECJ, Case C-264/12, Fidelidade Mundial, EU:C:2014:2036, and ECJ, Case C-665/13, Via Directa, EU:C:2014:2327. On 5 November 2013, the Tribunal do Trabalho de Lisboa sent another request for a preliminary ruling that challenged bailout measures. In Case C-566/13, Jorge Ítalo Assis dos Santos, OJ 2014/C $31 / 2$, the Court of Justice was questioned on the compatibility with the prohibition of discrimination laid down in Articles 20 and 21 of the Charter of the suspension of the holiday and Christmas allowances of retired workers of the Portuguese central bank (Banco de Portugal) included in Article 77 of the State Budget for 2013 (Law 66-B/2012, of 31 December). The reference also included questions of possible interference by the Government on the central bank's autonomy and independence (Article 130 TFEU) and on the breach of the prohibition of monetary financing of Member States by central banks (Article 123 TFEU). The case was removed from the docket of the court by an order of the President of the Court of Justice of 25 March 2014 (OJ C 31, 1. 2. 2014.).

IV ECJ, Case C-264/12, Fidelidade Mundial, EU:C:2014:2036, at 22, and ECJ, Case C-665/13, Via Directa, EU:C:2014:2327, at 16.

${ }^{v}$ ECJ, Case C-128/12, Sindicato dos Bancários do Norte, EU:C:2013:149, at 7.

VI ECJ, Case C-128/12, Sindicato dos Bancários do Norte, EU:C:2013:149, at 10-14.

VII ECJ, Case C-264/12, Fidelidade Mundial, EU:C:2014:2036, at 20.

vIII ECJ, Case C-264/12, Fidelidade Mundial, EU:C:2014:2036, at 20, and ECJ, Case C-665/13, Via Directa, EU:C:2014:2327, at 14.

Ix ECJ, Case C-128/12, Sindicato dos Bancários do Norte, EU:C:2013:149, para. 12, and ECJ, Case C-665/13, Via Directa, EU:C:2014:2327, a 13.

x I will only marginally discuss the compatibility of the MoU with the Portuguese Constitution. Article 8 (4) of the Portuguese Constitution recognizes that the legal authority of EU law in the Portuguese legal order
} 
must be established according to the parameters laid out by the EU legal order, but also declares that such a recognition is not unconditional, as it must comply with the fundamental principles of the democratic rule of law. In other words, the Portuguese Constitution recognizes the primacy of EU law as long as both legal systems are compatible in systemic terms. That compatibility can be found in the mutual respect of the fundamental principles of a democratic rule of law, which I will argue were breached with the adoption of the MoU. However, any constitutional review of the $\mathrm{MoU}$ is conditioned to a previous assessment of its validity by the Court of Justice in a preliminary reference submitted by Portuguese courts.

XI Statement of the Heads of State or Government of the Euro Area, p. 2, available at http://ec.europa.eu/archives/commission 2010-2014/president/news/speeches-

statements/pdf/114295.pdf.

XII Press release of the Extraordinary Council meeting of the Economic and Financial Affairs 9596/10, available at http://www.consilium.europa.eu/uedocs/cms data/docs/pressdata/en/ecofin/114324.pdf.

XIII That reads that 'the Union shall not be liable for or assume the commitments of central governments, regional, local or other public authorities, other bodies governed by public law, or public undertakings of any Member State, without prejudice to mutual financial guarantees for the joint execution of a specific project. A Member State shall not be liable for or assume the commitments of central governments, regional, local or other public authorities, other bodies governed by public law, or public undertakings of another Member State, without prejudice to mutual financial guarantees for the joint execution of a specific project.'

XIV ECJ, Case C-370/01, Pringle, ECLI:EU:C:2012:756, at 130 and 137. Previously to this decision of the Court of Justice, several commentators questioned the conformity of the financial assistance provided by the EFSF with Article 125 TFEU (Ruffert 2011: 1785; Menendez 2012: 90-91 and footnote 42).

XV The Articles of Agreement of the IMF state that access to the Fund's resources is conditioned by the presentation of 'adequate safeguards' by the State seeking financial assistance [Article I (v) and Article V (3) (a)]. The safeguards require the drafting and implementation of a program of economic and financial reforms capable of correcting the macroeconomic imbalances that created maladjustments in the balance of payments. The program is negotiated and presented in a letter of intent addressed to the Fund's Executive Board. In annex to that letter is usually included a memorandum that specifies the structural economic measures to be taken to correct imbalances and the key macroeconomic targets to be reached through the duration of the program. An IMF Executive Board decision named Stand-by Arrangement grants access to the Fund's general resources during a specified period and up to a certain amount [Article XXX (b)]. That access is conditioned to the accomplishment of certain macroeconomic objectives (quantitative performance criteria) and to the adoption of structural reforms that are crucial to the fulfillment of those objectives (structural benchmarks). Both the quantitative performance criteria and the structural benchmarks are included in the memorandum attached to the letter of intent sent by the State to the Executive Board. The first disbursement of the financial assistance is available immediately after the adoption of the Stanbyarrangement. Further disbursements are conditioned on a positive review by the Executive Board of the fulfillment of the conditionality included in the Stand-by Arrangement. See IMF Guidelines on Conditionality, para. 9 (Denters 2006: 196).

XVI The By-Laws of the EFSF were published in the Journal Officiel du Grand-Duché du Luxembourg, 8 Juin 2010, C, 1189, p. 570026, and are available at http://www.mf.public.lu/publications/divers/efsf memorial 080610.pdf.

XVII The framework-agreement is available at http://www.efsf.europa.eu/about/legal-documents/index.htm. XVIII In the history of European integration episodes abound of treaties that were not ratified after parliamentary decisions (e. g. the Treaty of the European Community of Defense, adopted in 1950, and abandoned two years afterwards with the rejection of its ratification by the French Parliament) or referenda (e. g. the Treaty Establishing a Constitution for Europe, signed in 2004, but rejected in 2005 in referenda held in France and in the Netherlands).

XIX The exercise of these tasks was authorized by a decision of the Eurozone Member States taken within the Ecofin meeting of 9 May 2010 ('Decision of the Representatives of the Governments of the Euro Area Member States Meeting within the Council of the European Union', published as Note 9614/10 of the General Secretariat of the Council, p. 2, available at http://register.consilium.europa.eu/pdf/en/10/st09/st09614.pt10.pdf). Although adopted within the meeting of an EU institution, this is a decision of Member States' representatives 'wearing their intergovernamental hats' (De Witte 2011: 6). In other words, Member States used their ius tractuum to allow EU institutions to participate in the EFSF. 
xx ECJ, Case C-370/01, Pringle, ECLI:EU:C:2012:756, at. 158.

xxi ECJ, Case C-370/01, Pringle, ECLI:EU:C:2012:756, at 162, and ECJ, Cases C-8/15 to C-10/95, Ledra, ECLI:EU:C:2016:701, at 56.

XXII Luxembourg common courts have also jurisdiction regarding disputes emerging from the loan agreement adopted between the Commission, the Portuguese government and the Bank of Portugal (Article 14, n. ${ }^{\circ}$, executive version of 24 and 25 May 2012, available at www.efsf.europa.eu/attachments/efsf portugal ffa.pdf).

XXIII ECJ, Case C-370/01, Pringle, ECLI:EU:C:2012:756, at 173-174.

xxIv See Article 199 (g) of the Portuguese Constitution. This provision was invoked to justify the competence of the Government to sign both the MoU and the loan agreements with the IMF, the EFSM and the EFSF (see Resolution 8/2011, published in Diário da República, II Série, 95, 17 May 2011). It is also mentioned in an opinion of the Portuguese Secretary of State for the Presidency of the Council of Ministers that endorses the constitutionality of both the MoU and the loan agreements (see paras. 13 e 14 of the opinion included in Annex II to the loan agreement signed between the Commission, the Portuguese Government and the Bank of Portugal; executive version of 24 and 25 May 2012, available at www.efsf.europa.eu/attachments/efsf portugal ffa.pdf). At least regarding the competence to adopt the loan agreements, the opinion of the Secretary of State is not in accordance with Article $161(\mathrm{~h})$ of the Constitution that requires the Government to ask for Parliament's authorization 'to contract and grant loans and engage in other lending operations, apart from floating debt operations, laying down the general terms and conditions governing such loans and lending operations, and setting the upper limit for guarantees to be given by the Government in any given year'.

Xxv The Portuguese President ratifies international treaties [Article 135 (b) of the Constitution] and signs resolutions of the Parliament and from the Council of Ministers that approve international agreements [Article 134 (b) of the Constitution].

XXVI 'Decision of the Representatives of the Governments of the Euro Area Member States Meeting within the Council of the European Union', published as Note 9614/10 of the General Secretariat of the Council, p. 2, available at http://register.consilium.europa.eu/pdf/en/10/st09/st09614.pt10.pdf.

XXVII This provision authorizes the Council to adopt specific measures to those Member States whose currency is the Euro with the scope of: i) strengthening the coordination and surveillance of their budgetary discipline; and ii) setting out economic policy guidelines for them, while ensuring that they are compatible with those adopted for the whole of the Union and are kept under surveillance.

xxvIII MEMO/11/227, available at http://europa.eu/rapid/press-release MEMO-11-227 en.htm. During the 'European Debt Crisis', the Ecofin and the Eurogroup regularly adopted joint declarations and press releases $\quad(e . \quad g . \quad$ Ecofin Communication 9614/10, available at http://register.consilium.europa.eu/pdf/en/10/st09614.en10.pdf). This communication technique is questionable vis-à-vis the principle of transparency (Article 1 of the TEU), as it joins one institution of the Union (Ecofin) and an informal political body (Eurogroup) that have members that do not coincide [the Ministers for Finance of all Member States (Ecofin) and the Ministers for Finance of Eurozone Member States (Eurogroup)] and are involved in different bailout mechanisms [EFSM (Ecofin) and the EFSF (Eurogoup)]. The Court of Justice recently declared that the Eurogroup is not among the different configurations of the Council and 'cannot be equated with a configuration of the Council or be classified as a body, office or agency of the European Union within the meaning of Article 263 TFEU' (Joined Cases C-105/15 P to C-109/15 P, Mallis and others, ECLI:EU:C:2016:702, at 61).

xxIx This decision was published in the OJ L 159/88 with the date of approval of 30 May, later corrected to 17 May in a corrigendum (see OJ L 178, p. 15). No legal consequences stem from this mistake because the Portuguese State is the sole addressee of the Decision (Article 5). According to Article 297 (2) (\$3) TFEU the effects of decisions are produced upon notification of the addressee.

xxx The swiftness in the signature of the MoU was due to the fact that the first disbursement of the financial assistance was linked to its entry into force [Article 1 (4) Decision 344/2011/EU]. The emergency of the moment probably explains why the Council Implementing Decision is not numbered in the preamble of the MoU.

xxxi On 3 May 2011, a slightly modified version of the MoU was signed between the Portuguese Government and the right-wing opposition parties (PPD/PSD and CDS/PP) (English version available at http://aventadores.files.wordpresscom/2011/05/memorando troika-en.pdf). The bailout request was made just after the resignation of the Portuguese (Socialist) Government following the Parliament's refusal to adopt further austerity measures included in a fourth version of the Stability and Growth Pact presented to 
Parliament on 23 March 2011. The commitment of the main opposition parties to the MoU was a requirement of the EU and the Eurogroup that is clearly underlined in the joint declaration of 8 April 2011, where it is stated that negotiations shall include those parties and calls for all political parties in Portugal to swiftly sign the MoU and confirm a new government in Parliament with the ability to fully adopt and implement the MoU. This declaration was made less than two months before Parliamentary elections in Portugal. Therefore, it may be regarded as an unlawful interference in the domestic affairs of the Portuguese State forbidden both by international law [Article 2 (7) of the United Nations Charter] and EU law [Article 4 (2) TUE].

XXXII Ecofin Press release 10231/11, available at http://www.consilium.europa.eu/uedocs/cms data/docs/pressdata/en/Ecofin/122047.pdf, where it is stated that 'The EU will provide loans amounting to EUR 52 billion as part of a EUR 78 billion package of financial assistance, with EUR 26 billion respectively granted under the European Financial Stability Mechanism (EFSM) and the European Financial Stability Facility. The IMF will provide around EUR 26 billion under an Extended Fund Facility'. This press release is just another example of the lack of transparency of bailout procedures. The Ecofin cannot act (or speak) on behalf of a mechanism of financial assistance that only includes Eurogroup Member States (the EFSF).

xxxiII This statement is included in the last part of footnote one of the MoU (http://ec.europa.eu/economy finance/eu borrower/mou/2011-05-18-mou-portugal en.pdf).

xxxiv A different path was taken in the second bailout to Greece that included financial support by the EFSF based on the conditions included in an autonomous memorandum signed on 1 March 2012 between the Commission and Greece (see http://ec.europa.eu/economy finance/eu borrower/mou/2012-03-01-greecemou en.pdf).

Xxxv The original and updated versions of the MoUs are available at http://www.portugal.gov.pt/pt/osmnisterios/primeiro-ministro/secretarios-de-estado/secretario-de-estado-adjunto-do-primeiroministro/documentos-oficiais/memorandos.aspx.

xxxvi Case 353/2012 (5 July 2012) (State Budget for 2012). All decisions from the Portuguese Constitutional Court are available in Portuguese at www.tribunalconstitucional.pt.

XxxviI See article 1 (4) of Decision 2011/344/EU. This EU-leg of the bailout was missing in some of the Member State's bailouts during the crisis. In Ledra, the Court of Justice rejected the qualification as EU law of the MoU adopted in a bailout requested by Cyprus to the European Stability Mechanism (ESM) (Cases C8/15 to C-10/95, Ledra, ECLI:EU:C:2016:701, at 54). The ESM was identified as an international agreement signed outside the EU legal framework (Advocate-General Whal, Cases C-8/15 to C-10/95, Ledra, ECLI:EU:C:2016:701, at 51).

xxxviII See Council Recommendation on the National Reform Programme 2012 of Portugal and delivering a Council opinion on the Stability Programme of Portugal, 2012-2016, of 6 July 2012, 11268/12, available at http://register.consilium.europa.eu/doc/srv?l=EN\&f=ST $\% 2011268 \% 202012 \% 20 I N I T, \quad$ or Council Recommendation (COM) 566/2012, of 2 of October, 14238/12, available at http://register.consilium.europa.eu/doc/srv?l=EN\&f=ST\%2014238\%202012\%20INIT.

xxxIx ECJ, Case 322/88, Grimaldi, EU:C:1989:646, at 18.

XL ECJ, Case C-617/10, Fransson, EU:C:2013:280, at 21.

XLI ECJ, Cases C-8/15 to C-10/95, Ledra, ECLI:EU:C:2016:701, at 59.

XLII The original version of the MoU included pension cuts of around $445 €$ million in pensions (1.11) and savings of $195 €$ million in education (1.8) and $550 €$ million in the health-care system (1.10).

XLIII In the pending Case T-531/14, Sotiropoulou, OJ C 351, the CFI will decide on a claim of a breach of the principles of conferral and subsidiarity in an action for damages brought against bailout Council decisions addressed to Greece. In 2010, the CFI rejected a similar action based on the applicants' lack of direct concern within the meaning of the fourth paragraph of Article 263 TFEU. The Court considered, however, that the applicants had the possibility of attacking national implementing measures 'before the national courts and, in the context of that dispute, arguing that the contested (EU law) acts are invalid, thus leading the national court to refer a question for a preliminary ruling to the Court of Justice' (CFI, Case T-541/10, ADEDY, ECLI:EU:T:2012:626, at 87 and 90). XLIV ECJ, Case C-201/08, Plantanol, EU:C:2009:539, at 43.

XLV ECJ, Case C-146/11, AS Pimix, ECLI:EU:C:2012:450, at 36.

XLVI Very appropriately, the Portuguese chose the adjective "entroikado" (a new word) as the word-of-theyear for 2012 (see http://www.portoeditora.pt/imprensa/noticia/ver/portugueses-elegem-entroikado-comoa-palavra-do-ano-2012?id=6901). It means to be 'forced to live under the conditions imposed by the Troikea (team 
constituted by members of the European Commission, European Central Bank and International Monetary Fund that negotiated the financial bailout conditions in Portugal)' (Dicionário de Português|Inglês, Porto Editora, 2003-2016, available at www.infopedia.pt/dicionarios/portugues-ingles/entroikado).

XLVII ECJ, Case 161/06, Skoma-Lux, ECLI:EU:C:2007:773, at 33. Article 297 TFEU requires publication as a condition for the taking of effects by legislative or non-legislative EU legal acts, with the exception of directives and decisions that do not specify to whom they are addressed, which take effects with the notification to those to whom they are addressed.

XLVIII This is the expression used in the Portuguese translation made by the Portuguese government that also makes the caveat that in 'case of divergence between the English and Portuguese version, the English version prevails'. The translations of the original and updated $\mathrm{MoUs}$ are available at http://www.portugal.gov.pt/pt/osministerios/primeiro-ministro/secretarios-de-estado/secretario-de-estado-adjunto-do-primeiro-

ministro/documentos-oficiais/memorandos.aspx.

XLIX The fact that the Portuguese government and the Bank of Portugal used the English language in the letter of intent that included the MoU sent to the Commission on 13 May 2011 is irrelevant. Regarding requests for EFSM and EFSF financial support, the only version of the MoU that matters is the one signed on 17 May 2011.

${ }^{\mathrm{L}}$ ECJ, Cases C-584/10 P, C-593-10 P and C-595/10 P, Kadi, EU:C:2013:518.

LI ECJ, Cases C-584/10 P, C-593-10 P and C-595/10 P, Kadi, EU:C:2013:518, at 66; ECJ, Case C-584/10 P, Inuit, P, EU:C:2013:625, at 91; ECJ, Case C-274/12 P, Telefónica, EU:C:2013:852, at 56; ECJ, Case C-362/14, Schrems, EU:C:2015:650, at 60.

LII ECJ, Cases C-188/10 and C-189/10, Melki and Abdeli, EU:C:2010:363, at 54; ECJ, Case C-533/10, CIVAD, EU:C:2012:347, at 40.

LIII ECJ, Case 314-85, Foto-frost, EU:C:1987:453, at 20; ECJ, Case C-344/04, LATA, EU:C:2006:10, at 27.

LIV CFI, Case T-219/95, Marie-Thérèse Danielsson, ECLI:EU:T:1995:219, at 77.

LV ECJ, Case C-30/93, AC-ATEL, ECLI:EU:C:1994:224, at 16; ECJ, Case C-235/95, Dumont e Froment, ECLI:EU:C:1998:365, at 25; ECJ, Case C-107/98, Teckal, ECLI:EU:C:1999:344, at 29.

LVI ECJ, Case 6/64, Costa, ECLI:EU:C:1964:66, pp. 592 and 593.

LVII Legal complexity is mentioned by Kilpatrick (2015: 333-342), as one of the key rule of law challenges presented by the EU bailouts in debtor States.

LVIII IMF Guidelines on Conditionality, de 25 de setembro de 2002, n. 9 (Erik Denters 2006: 197).

LIX A clear example was the attempt to lower the TSU (Taxa Social Unica) - the business contribution to social security - in the summer of 2012. The idea was discussed during the negotiation of the adjustment program. On 12 May 2011, the Portuguese Finance Minister confirmed to a Portuguese newspaper (Público) that it had sent a letter to the IMF in which it is declared the commitment of the Portuguese Government to reduce the TSU (http://www.publico.pt/economia/noticia/financas-garantem-que-ideia-de-reduzir-a-tsu-nunca-foiomitida 1493848). In the MoU sent to the IMF on 17 May it is stated that 'A critical goal of our program is to boost competitiveness. This will involve a major reduction in employer's social security contributions. This measure will be fully calibrated by the time of the first review (end-July 2011, structural benchmark)' (at 39). The issue remained dormant until 8 September 2012 when the Prime-Minister announced its intention to increase the contribution of workers to the Social Security to $18 \%$ (an increase of $7 \%$ ). A few days later, when the social opposition to the announcement created a wave of massive demonstrations and many questioned whether the measure was part of the Troika conditionality, the IMF, though its chief of mission in Portugal, came public to declare that the changes introduced to the TSU were not included in the conditionality of the Fund's financial assistance: 'There were several budgetary measures that were discussed to be included in the State Budget Act for 2013. The TSU was one of them. But no, it was not a condition for anything else. This was an opinion that was put on the table. We thought it was reasonable and support it' (see http://www.publico.pt/economia/noticia/chefe-de-missao-do-fmi-simplesmentereduzir-os-salarios-nao-vai-resultar-1562825).

LX In the Report by the European Institutions on the role and operations of the Troika (ECB, Commission and IMF) with regard to the euro area programme countries [(2013/2277(INI)], available at http://www.europarl.europa.eu/sides/getDoc.do?pubRef=-//EP//TEXT+REPORT+A7-20140149+0+DOC+XML+V0//PT], the Committee on Economic and Monetary Affairs of the European Parliament regretted 'that the (bailout Eurozone countries) programs are not bound by the Charter of Fundamental Rights of the European Union, the European Convention of Human Rights and the European Social Charter, due to the fact that they are not based on Union primary law'. In their contributions to the European Parliament Report, both the ECB and the Commission rejected the idea that the MoU created any kind of legal obligations by declaring that 'the 
final decision on concrete measures to be taken at national level is adopted by the concerned Member States'
Questionnaire
response, https://polcms.secure.europarl.europa.eu/cmsdata/upload/f13d8652-15b7-4945-beb7ce52a447c7d7/att 20140114ATT77317-4182200006287211655.pdf) that have to 'ensure that its obligations regarding fundamental rights are respected (Commission Questionnaire response, p. 5, available at https://polcms.secure.europarl.europa.eu/cmsdata/upload/db6df1cd-bcdf-437f-aa6e-

4f1aaa16f371/att 20140114ATT77315-2012338784114975647.pdf). On this topic, see Kilpatrick (2014: 394396).

LXI ECJ, Case C-346/05, Monique Chateignier, ECLI:EU:C:2006:711, at 18. See also ECJ, Case C-17/92, Teckeal, ECLI:EU:C:1993:172, at 8.

LXII ECJ, Case C-264/12, Fidelidade Mundial, EU:C:2014:2036, at 4, and ECJ, Case C-665/13, Via Directa, EU:C:2014:2327, at 4.

LXIII ECJ, Case C-264/12, Fidelidade Mundial, EU:C:2014:2036, at 19, and ECJ, Case C-665/13, Via Directa, EU:C:2014:2327, at 13.

LXIV ECJ, Cases C-8/15 to C-10/95, Ledra, ECLI:EU:C:2016:701, at 91.

LXV Joerges (2014: 44) identifies in the Portuguese Constitutional Court case law a 'signal' of judicial opposition against the European crisis management, although it recognizes that it is a rather weak signal since the implementation of austerity measures was objected on the basis of the violation of the principle of proportionality and equality.

LXVI In this case, the Portuguese Constitutional Court limited the effects of the declaration of unconstitutionality of the provisions that suspended the holiday and Christmas salaries in the public sector. The Constitutional Court decision had no practical effects because the cuts were allowed to be applied until the end of the tax year (which was the temporal limit for the State Budget Act for 2012). This was the broader application ever adopted of Article 282 (4) of the Constitution. This provision allows the Constitutional Court to restrict the effects of a decision of unconstitutionality based on 'an exceptionally important public interest'.

LXVII A thorough explanation in English of the most relevant decisions of the so-called "austerity case law" of the Portuguese Constitutional Court was made by Canotilho, Violante and Lanceiro (2015: 155-183).

LXVIII In case 353/2012 (State Budget Act for 2012), the Portuguese Constitutional Court recognized that the country was 'in a very serious economic and financial situation, in which it (was) important to achieve the public deficit objectives set out in the memoranda of understanding in order to ensure the financial solvability of the State', but declared that the austerity program had to be applied fairly. The Court did not adopt a 'crisis law' standard of adjudication and refuse to accept the argument of the financial emergency of the State as a blank justification for austerity measures (Urbano 2014: 14-15). Instead, it went through a case-by-case analysis of each measure, accepting some (mostly transitory) and rejecting others, either because they breached the principle of equality, failed the proportionality test or did not meet legitimate expectations. This case law was praised by some commentators [the most notorious being Novais 2014], but criticized by others that accused the Court of inconsistency and of engaging in judicial activism [Almeida Ribeiro and Pereira Coutinho 2014].

LXIX See, however, the second update of the MoU - quoted above in Section 1 - that requires the suspension of the holiday and Christmas monthly salary payments in para. 1.8., i).

LXx In case 163/90 (23 May 1990), the Portuguese Constitutional Court recognized that it is bound by the duty to refer preliminary questions to the Court of Justice foreseen in Article 267 (3) TFUE. Remarkably, however, more than a quarter of Century later, the Court never had any doubts that required the preliminary intervention of the Court of Justice. Not even when in Case 141/2015 (25 February 2015) declared that the principle of equality (Article 13 of the Constitution) was breached by a provision that conditioned the grant of a social benefit to a one-year minimum legal residence in the Portuguese territory. This decision was taken with dissenting (Maria Lúcia Amaral) and even concurring opinions of judges (João Caupers) that argued that a reference for a preliminary ruling should have been made in order to solve doubts on the scope of the reasoning of the Court of Justice in Case C-333/13, Dano, ECLI:EU:C:2014:2358. In Case 283/81, Cilfit, ECLI:EU:C:1982:335, at 16, the Court of Justice introduced an exception to the duty to refer when the correct application of EU law is 'so obvious as to leave no scope for any reasonable doubt'. The existence of doubts regarding the interpretation of EU law in concurring and dissenting opinions is enough to trigger the duty to refer of a national court 'against whose decisions there is no judicial remedy under national law' [Article 267 (3) TFUE]. This situation differs from the Case C-160/14, Ferreira da Silva e Brito, EU:C:2015:565, paras. 41-42, where the Court of Justice devalued the importance of lower national courts adopting contradictory decisions on EU 
law, which in itself would not preclude the apex court from finding a particular interpretation of EU law to be beyond reasonable doubt.

LXXI ECJ, Case C-362/14, Schrems, EU:C:2015:650, at 60.

LXxiI ECJ, Cases C-8/15 to C-10/95, Ledra, ECLI:EU:C:2016:701, at 68

LXXIII In the pending Case C-258/14, Florescu, the Court of Justice will have the opportunity to confirm this approach in a preliminary reference that questions the compatibility with the Charter of a memorandum signed in 2009 between the Commission and Romania within the framework of an EU bailout to a noneurozone Member State (Article 143 TFEU).

\section{References}

- $\quad$ Almeida Ribeiro Gonçalo de and Pereira Coutinho Luís (eds), 2014, O Tribunal Constituticional e a Crise: ensaios críticos, Almedina, Coimbra.

- Barnard Catherine, 2013, 'The Charter in Time of Crisis: A Case Study of Dismissal', in Nicola Countouris and Mark Freedland (eds), Resocialising Europe in a Time of Crisis, Cambridge University Press, Cambridge, 250-277.

- Canotilho Mariana, Violante Teresa and Lanceiro Rui, 2015, 'Austerity measures under judicial scrutiny: the Portuguese constitutional case-law', European Constitutional Law Review, XI(1): 155-183.

- Costamagna Francesco, 2012, 'Saving Europe "Under Strict Conditionality": a threat for EU social dimension?', Working Paper-LPF no. 7, available at http://www.centroeinaudi.it.

- De Witte Bruno, 2011, 'The European Treaty Amendment for the Creation of a Financial Stability Mechanism' in SIEPS European Policy Analysis, available at http://www.eui.eu/Projects/EUDOInstitutions/Documents/SIEPS20116epa.pdf.

- $\quad$ Denters Erik, 2006, International Monetary Fund (IMF), Kluwer, Alphen aan den Rijn.

- $\quad$ European Commission, 2011, 'The Economic Adjustment Programme for Portugal. Second Review Autumn 2011' in Occasional Papers, 89, available at http://ec.europa.eu/economy finance/publications/occasional paper/2011/pdf/ocp89 en.pdf.

- $\quad$ Fischer-Lescano Andreas, 2014, 'Human Rights in Times of Austerity Policy - The EU institutions and the conclusion of Memoranda of Understanding', Centre of European Law and Politics (ZERP), Bremen, available at https://www.etuc.org/sites/www.etuc.org/files/pressrelease/files/legal opinion human rights in times of austerity policy final.pdf.

- Joerges Christian, 2014,'Three Transformations of Europe and the Search for a Way Out of its Crisis', in Christian Joerges and Carola Glinski (eds), The European Crisis and the Transformation of Transnational Governance: authoritarian managerialism vs democratic governance, Hart, Oxford, Chapter one.

- $\quad$ Kilpatrick Claire, 2014, 'Are the Bailouts Immune to EU Social Challenge because They Are Not EU Law’, European Constitutional Law Review, X(3): 393-421.

- $\quad$ Kilpatrick Claire, 2015, 'On the Rule of Law and Economic Emergency: The Degradation of Basic Legal Values in Europe's Bailouts', Oxford Journal of Legal Studies, XXXV(2): 325-353.

- Koukiadaki Aristea, 2014, 'Can the Austerity Measures be Challenged in Supranational Courts? The cases of Greece and Portugal', University of Manchester, Manchester, available at https://www.etuc.org/sites/www.etuc.org/files/publication/files/austerity greeceportugal en 3.pdf.

- López Escudero Manuel, 2015, 'La Nueva Governanza Económica de la Unión Europea: ¿Una auténtica unión económica en formación?’, Revista de Derecho Comunitario Europeo, no. 50: 361-433.

- Martín Rodríguez Pablo, 2016, 'A Missing Piece of European Emergency Law: Legal Certainty and Individuals' Expectations in the EU Response to the Crisis', European Constitutional Law Review, XII(2): 265293.

- Menendez Agustín José, 2012, 'La mutación constitutional de la Unión Europea', Revista Española de Derecho Constitucional, no. 96: 41-98.

- Miranda Jorge, 2013, 'Sobre o memorando de entendimento entre Portugal e a "Troika"”, in Eduardo Paz Ferreira (ed), Troika Ano II. Uma avaliação de 66 cidadãos, Edições 70, Lisboa, 315-318. 
- $\quad$ Nogueira de Brito Miguel, 2014, 'Putting Social Rights in Brackets? The Portuguese Experience with Welfare Challenges in Times of Crisis', in Claire Kilpatrick and Bruno de Witte (eds), Social Rights in Times of Crisis in the Eurozone: The Role of Fundamental Rights, EUI Working Paper 2014/05, 67-77.

- $\quad$ Reis Novais Jorge, 2014, Em Defesa do Tribunal Constitucional: resposta aos críticos, Almedina, Coimbra.

- Pereira Coutinho Francisco, 2013, 'A natureza jurídica dos memorandos da "Troika"”, Themis, no. 24/25: 147-179.

- $\quad$ Piçarra Nuno, 2013, 'Sobre a repartição de competência do Tribunal de Justiça da União Europeia', Revista do Ministério Público, no. 133: 11-74.

- Piçarra Nuno and Francisco Pereira Coutinho, 2012, 'The Europeanization of Portuguese Courts', Silesian Journal of Legal Studies, IV: 73-88.

- Ruffert Matthias, 2011, 'The European Debt Crisis and the European Union Law', Common Market Law Review, XLVIII(6): 1777-1806.

- Siegel Deborah E., 2002, 'Legal Aspects of the IMF/WTO Relationship: the fund's articles of agreement and the WTO agreements', American Journal of International Law, XCV(3): 561-621.

- Tuori Kaarlo, 2012, 'The European Finantial Crisis - Constitutional Aspects and Institutions', EUI Working Papers Law no. 2012/28, 2012, available at http://papers.ssrn.com/sol3/papers.cfm?abstract id=2171824.

- Urbano Maria Benedita, 2014, ‘A Jurisprudência da Crise no Divâ. Diagnóstico: Bipolaridade?’, in Gonçalo de Almeida Ribeiro and Luís Pereira Coutinho (eds), O Tribunal Constituticional e a Crise: ensaios críticos ("The Constitutional Court and the Crisis: critical essays"), Almedina, Coimbra, 8-48.

- Vilhena de Freitas Lourenço, 2015, 'The Judicial Activism of the European Court of Justice', in Luís Pereira Coutinho, Massimo La Torre and Steven D. Smith (eds), Judicial Activism: an Interdisciplinary Approach to the American and European Experiences, Springer, Heidelberg etc., 173-180. 